\title{
Site Variation in Forage Qualities of Mountain Ma- hogany and Serviceberry
}

\author{
ROLAND C. KUFELD, MARILYN L. STEVENS, AND DAVID C. BOWDEN
}

\begin{abstract}
Nutrient and fiber content and in vitro digestible dry matter (IVDDM) were measured in mountain mahogany (Cercocarpus montanus) and serviceberry (Amelanchier alnifolia) samples collected during January from 8 geographic areas distributed throughout the western half of Colorado. Coefficients of variation (CV) in dry matter content, cell content, crude protein, soluble carbohydrate, cell walls, holocellulose and IVDDM were $10 \%$ or less for both species. Winter variation in these parameters appears to be small enough to permit using a constant value for them in calculating winter nutritional status of big game rangelands.
\end{abstract}

Effective management of big game range requires knowledge of the nutritional value of important forage plants during the critical winter period. Forage species which comprise winter big game diets must be adequate in nutrient content to meet minimum animal requirements.

Current procedures for evaluating nutritional status of winter rangelands involves chemical analysis of each forage species or of diet mixes to determine nutrient content (Wallmo et al. 1977, Hobbs et al. 1982). These analyses are time consuming and expensive. If several winter ranges were being evaluated, the time and cost of a detailed analysis of each plant species on each range could be prohibitive. Costs of evaluating a number of ranges could be reduced if variation among plants of the species was small enough to permit application of suitably selected constants to reflect winter nutrient content, fiber content, and digestiblity of a species regardless of where collected. Sampling forage quality of individual species on each rangeland area of interest would then not be necessary. For management purposes, it may be adequate to determine whether the composite nutrient level for an area of rangeland (average nutrient levels for each forage species on an area combined and weighted by their percent herbage composition) exceeds some minimum value rather than to measure actual composite nutrient levels.

In a previous study (Kufeld et al. 1981), samples of gambel oak (Quercus gambellii) and big sagebrush (Artemisia tridentata) were collected during January from 9 geographic areas distributed throughout the western half of Colorado. These species had coefficients of variation (CV) among areas that were less than $10 \%$ for dry matter content, in vitro digestible dry matter (IVDDM), and most cell and cell wall components.

The objective of this study was to determine variation in nutrient content and digestiblity of mountain mahogany (Cercocarpus montanus) and serviceberry (Amelanchier alnifolia) growing under widely diversified conditions and in different geographic locations within western Colorado.

\section{Materials and Methods}

Our sampling system was designed to encompass the range of environmental site factors existing within mountain mahogany and serviceberry habitat in western Colorado. The design maximized distances and elevation levels between plant collection locations and included samples from the major vegetation types in

\footnotetext{
Authors are wild life researcher and wildlife technician, Colorado Division of Wildlife, Fort Collins, Colo. 80526; and associate professor, Statistics Department, Colorado State University, Fort Collins 80523 .

Research was funded in part by Federal Aid in Fish and Wildlife Restoration Colorado Project W-126-R.

Manuscript accepted January 10, 1985
}

which each species occurs in Colorado. The objective was to encounter as much geographic variation in nutrient and fiber and content and digestiblity as possible within each plant species.

During January, 1979, samples of mountain mahogany and serviceberry were collected from 8 widely distributed geographic areas throughout the western half of Colorado. The 8 areas where mountain mahogany samples were collected were not always the same as the areas where serviceberry samples were collected. For each species, the 8 areas represented 2 major vegetation types as described by Costello (1954). Mountain mahogany samples were collected from 4 geographic areas where mountain mahogany was the dominant vegetation, and from 4 areas where pinyon-juniper (Pinus edulis-Jumiperus osteosperma) was dominant. Four areas where serviceberry samples were collected represented the gambel oak-serviceberry type and 4 areas represented the pinyon-juniper type.

A single sample (70-100 g, green weight) of each species was collected at each of 5 sites within each geographic area. Each sample was a composite from 15 to 30 plants growing on a site. The 5 collection sites within each geographic area were distributed throughout the area and separated by distances of at least $8 \mathrm{~km}(5$ mi) and often 32 to $48 \mathrm{~km}$ ( 20 to $30 \mathrm{mi})$. Collection sites were diversified elevationally and in steepness of slope and aspect.

Plant collections consisted of current annual growth stems; leaf remnants were excluded. A portion of each sample was air dried, then oven dried, ground, and analyzed for the following: dry matter; total cell contents, including crude protein (Kjeldahl $\mathbf{N} \times$ 6.25), ether extract, soluble ash, and soluble carbohydrate (Association of Official Agricultural Chemists 1965); total cell walls including acid insoluble ash, lignin, hemicellulose, cellulose, holocellulose (Fonnesbeck and Harris 1970a, 1970b, 1971). The remaining portion of each sample was used to determine IVDDM using Pearson's (1970) modification of the method described by Tilley and Terry (1963). Inoculum was from a Holstein cow maintained on native grass hay. Data were analyzed by analysis of variance with geographic areas nested within vegetation types.

\section{Results and Discussion}

Most nutrient and fiber components in both mountain mahogany and serviceberry differed $(P<.05)$ among vegetation types, among geographic areas, and among areas within vegetation types. Even though differences occurred which are statistically significant, the degree of variation as reflected by $\mathrm{CV}$ among the 8 area means (Tables 1 and 2 ) was relatively small. Thus, data reflect relatively little mid-winter variation from one locality to another in content of most nutrients and fiber components in both species. The CV in dry matter content, cell content, crude protein, soluble carbohydrate, cell walls, and holocellulose were all less than $10 \%$ for both shrub species.

The CV a mong area means for IVDDM was $3.8 \%$ for mountain mahogany and $10.0 \%$ for serviceberry (Tables 1 and 2). If, for example, yield of digestible forage during winter was being measured on several parcels of western Colorado rangelands, use of mean or median IVDDM values of $29.7 \%$ and $29.4 \%$, respectively, for mountain mahogany and $30.1 \%$ or $31.0 \%$, respectively, for serviceberry should provide a relatively accurate estimate of IVDDM for those species.

Minimum values for the range of each mean (Tables 1 and 2) 
Table 1. Percent nutrient content in mountain mahogany collected during January 8 from 8 geographic areas distributed throughout western Colorado. 1

\begin{tabular}{|c|c|c|c|c|c|c|}
\hline \multirow[b]{3}{*}{ Nutrient } & \multicolumn{6}{|c|}{8 Geographic area means } \\
\hline & \multirow[b]{2}{*}{ Mean } & \multirow{2}{*}{$\begin{array}{c}\text { Standard } \\
\text { deviation (SD) }\end{array}$} & \multirow{2}{*}{$\begin{array}{c}\text { Coefficient of } \\
\text { variation }(\mathrm{CV}) \\
(\%)\end{array}$} & \multicolumn{3}{|c|}{ Range $^{2}$} \\
\hline & & & & Minimum & Maximum & Median \\
\hline Dry matter content & 66.4 & 1.2 & $\begin{array}{c}1.8 \\
\text { Cell Contents }\end{array}$ & 64.3 & 68.0 & 66.6 \\
\hline Crude protein & 6.4 & 0.4 & 6.6 & 5.9 & 7.1 & 6.4 \\
\hline Soluble carbohydrate & 33.2 & 3.1 & 9.3 & 27.5 & 36.7 & 32.9 \\
\hline Ether extract & 4.1 & 1.4 & 33.7 & 2.2 & 6.3 & 4.4 \\
\hline Soluble ash & 2.3 & 0.3 & 14.3 & 1.9 & 2.8 & 2.3 \\
\hline Total Cell Contents & 46.0 & 2.3 & $\begin{array}{l}5.1 \\
\text { Cell Walls }\end{array}$ & 42.3 & 49.9 & 45.2 \\
\hline Lignin & 19.2 & 2.4 & 12.2 & 15.9 & 23.1 & 18.9 \\
\hline Hemicellulose & 8.2 & 1.7 & 20.4 & 5.9 & 11.0 & 8.4 \\
\hline Cellulose & 26.4 & 3.3 & 12.4 & 20.2 & 30.2 & 26.9 \\
\hline Holocellulose & 34.7 & 2.8 & 8.1 & 28.9 & 38.3 & 35.2 \\
\hline Insoluble ash & 0.2 & 0.2 & 91.2 & 0.0 & 0.5 & 0.2 \\
\hline Total Cell Walls & 54.0 & 2.3 & $\begin{array}{c}4.3 \\
\text { Digestibility }\end{array}$ & 50.1 & 57.7 & 54.8 \\
\hline $\begin{array}{l}\text { In vitro digestible dry matter } \\
\text { (IVDDM) }\end{array}$ & 29.7 & 1.1 & 3.8 & 28.8 & 32.4 & 29.4 \\
\hline
\end{tabular}

'Data are based on collections of 5 samples from widely separated locations within each of 8 geographic areas throughout western Colorado.

2Minimum and maximum range values also represent the $95 \%$ confidence interval for the median of area means as calculated using procedures described by Dixon and Massey (1969) p. 349.

Values are based on $100 \%$ dry matter.

Table 2. Percent nutrient content in serviceberry collected during January from 8 geographic areas distributed throughout western Colorado.'

\begin{tabular}{|c|c|c|c|c|c|c|}
\hline \multirow[b]{3}{*}{ Nutrient } & \multicolumn{6}{|c|}{8 Geographic area means } \\
\hline & \multirow[b]{2}{*}{ Mean } & \multirow{2}{*}{$\begin{array}{c}\text { Standard } \\
\text { deviation }(\mathrm{SD})\end{array}$} & \multirow{2}{*}{$\begin{array}{l}\text { Coefficient of } \\
\text { variation }(\mathrm{CV}) \\
\qquad(\%)\end{array}$} & \multicolumn{3}{|c|}{ Range $^{2}$} \\
\hline & & & & Minimum & Maximum & Median \\
\hline Dry matter content & 61.9 & 1.1 & $\begin{array}{c}1.8 \\
\text { Cell Contents }\end{array}$ & 60.5 & 63.9 & 61.7 \\
\hline Crude protcin & 6.2 & 0.6 & 9.5 & 5.0 & 6.7 & 6.4 \\
\hline Soluble carbohydrate & 29.8 & 2.4 & 7.9 & 26.2 & 32.9 & 29.9 \\
\hline Ether extract & 2.5 & 0.7 & 27.0 & 1.6 & 3.5 & 2.6 \\
\hline Soluble ash & 1.8 & 0.4 & 21.9 & 1.3 & 2.4 & 1.6 \\
\hline Total Cell Contents & 40.3 & 2.2 & $\begin{array}{c}5.5 \\
\text { Cell Walls }\end{array}$ & 36.3 & 43.3 & 40.5 \\
\hline Lignin & 18.9 & 2.0 & 10.5 & 16.7 & 22.8 & 18.7 \\
\hline Hemicellulose & 8.2 & 2.0 & 24.3 & 6.5 & 11.4 & 7.2 \\
\hline Cellulose & 32.5 & 4.7 & 14.4 & 24.4 & 38.3 & 33.2 \\
\hline Holocellulose & 40.7 & 3.6 & 8.9 & 35.0 & 44.8 & 40.9 \\
\hline Insoluble ash & 0.5 & 0.2 & 37.4 & 0.1 & 0.7 & 0.5 \\
\hline Total Cell Walls & 59.8 & 2.2 & $\begin{array}{c}3.7 \\
\text { Digestibility }\end{array}$ & 56.7 & 63.7 & 59.7 \\
\hline $\begin{array}{l}\text { In vitro digestible dry matter } \\
\text { (IVDDM) }\end{array}$ & 30.1 & 3.0 & 10.0 & 26.7 & 35.3 & 31.0 \\
\hline
\end{tabular}

Data are based on collections of 5 samples from widely separated locations within tach of 8 geographic areas throughout western Colorado.

${ }_{2}^{2}$ Minimum and maximum range values also represent the $95 \%$ confidence interval for the median of a rea means as calculated using procedures described by Dixon and Massey (1969) p. 349.

Values are based on $100 \%$ dry matter.

represent one-sided, nonparametric, lower tolerance limits for dry matter, nutrient, and fiber components and digestiblity for each species (Dixon and Massey 1968, p. 348). These can be used to reflect the proportion of ranges (or areas) with plant nutrient, fiber or digestiblity levels above the smallest mean area value at a given level of confidence. For example, these values might be used as follows: using 8 area samples means (based on 5 samples per area) which range from $28.8 \%$ to $32.4 \%$ IVDDM for mountain mahogany (Table 1) one can be $95 \%$ sure that at least $70 \%$ of the geographic mean IVDDM values encountered in mountain mahogany in Colorado, during January, would exceed the minimum value of $28.8 \%$. By using the minimum value, one could be reasonably sure the estimate of IVDDM is conservative.

The relatively small degree of variation among locations in nutrient, fiber content and IVDDM in mountain mahogany and serviceberry during winter is consistent with that found in gambel oak and big sagebrush (Kufeld et al. 1981). Variation in nutrient and fiber content and IVDDM appears to be small enough to permit application of mean or medium values for all 4 species with sufficient accuracy to estimate available nutrients on rangelands for management purposes. One-sided nonparametric tolerance levels (Dixon and Massey 1969, p. 348) can be employed to ensure 
that estimates of nutrient and fiber production and digestiblity based on such data are conservative.

Data presented herein reflect spatial but not temporal variation. We suggest that use of a constant value to estimate nutrient quality of additional range plants also incorporate data reflecting year-toyear variation.

\section{Literature Cited}

Association of Official Agricultural Chemists. 1965. Official methods of analysis. Ass. Official Agr. Chem., Washington, D.C. 10th ed.

Costello, D.F. 1954. Vegetation zones in Colorado, p. iii-x In: H.D. Harrington (ed.), Manual of the plants of Colorado. Sage Books, Denver, Colo.

Dixon, W.J., and F.J. Massey, Jr. 1969. Introduction to statistical analysis. McGraw-Hill, New York. 3rd ed.

Fonnesbeck, P.V., and L.E. Harris. 1970n. Determination of plant cell walls in feeds. Proc. Western Sec. Amer. Soc. Anim. Sci. 21:153-161.

Fonnesbeck, P.V., and L.E. Harris. 1970b. Determination of holocellulose lignin and silica of plant cell walls. Proc. Western Sec. Amer. Soc. Anim. Sci. 21:162-164.
Fonnesbeck, P.V., and L.E. Harris. 1971. Determining hemicellulose in plant cell walls. Proc. Western Sec. Amer. Soc. Anim. Sci. 22:77-82.

Hobbs, N.T., D.L. Baker, J.E. Ellis, D.M. Swift, and R.A. Green. 1982. Energy - and nitrogen-based estimates of elk winter-range carrying capacity. J. Wildl. Manage. 46:12-21.

Kufeld, R.C., M. Stevens, and D.C. Bowden. 1981. Winter variation in nutient and fiber content and in vitro digestibility of Gambel oak (Quercus gambellii) and big sagebrush (Artemisia tridentata) from diversified sites in Colorado. J. Range Manage. 34:149-151.

Pearson, H.A. 1970. Digestibility trials: in vitro techniques, p. 85-92. In: H.A. Pautson and E.H. Reid (eds.), Range and wildlife habitat evaluation-a research symposium. USDA Forest Serv. Misc. Pub. No. 1147.

Tilley, J.M.A., and R.A. Terry. 1963. A two-stage technique for the in vitro digestion of forage crops. J. Brit. Grassl. Soc. 18:104-111.

Wallmo, O.C., L.H. Carpenter, W.L. Regelin, R.B. Gill, and D.L. Baker. 1977. Evaluation of deer habitat on a nutritional basis. J. Range Manage. 30:122-127.

\section{Faculty Position in Fisheries Management}

The Department of Range and Wildlife Management at Texas Tech University is seeking applicants for an assistant or associate professor position in fisheries management starting Janury 15, 1986. The successful candidate is expected to teach courses related to fisheries, aquatic habitats, and ecology and conservation of natural resources. Research responsibilities are open to the specific interests of the individual. Opportunities exist in warm water fish biology in west Texas, study of genetics, pesticide residues in terrestrial and aquatic ecosystems, and investigations of water quality. Applicants must have a Ph.D. Submit letter of application, curriculum vitae, an outline of research interests, and have three letters of recommendation sent by 31 October 1985 (or until a suitable candidate can be identified) to: Dr. Henry A. Wright, Department of Range and Wildlife Management, Texas Tech University, P.O. Box 4169, Lubbock, Texas 79409 (An Equal Opportunity/Affirmative Action Employer).

Responsibilities-a) Teach the undergraduate course, Range Management and Improvement, and graduate courses such as Range Plant Communities and Range Watersheds. Graduate courses in the successful applicant's specialty will be encouraged. b) Advise undergraduate and graduate students in academic and research programs. c) Maintain a research program in the area of management of rangeland.

Applicants-Applicants should forward a curriculum vitae, three letters of recommendation, research interests to: Clayton N. Haugse, Chairman, Department of Animal and Range Sciences, Hultz Hall, North Dakota University, Fargo, North Dakota 58105.

NORTH DAKOTA STATE UNIVERSITY IS AN EQUAL OPPORTUNITY EMPLOYER 